The Community Forests of Mexico 
THIS PAGE INTENTIONALLY LEFT BLANK 


\section{The Community Forests of Mexico}

Managing for Sustainable Landscapes

EDITED BY DAVID BARTON BRAY,

LETICIA MERINO-PÉREZ, AND DEBORAH BARRY

University of Texas Press $\mathbf{v}$ Austin 
Support for this book comes from an endowment for environmental studies made possible by generous contributions from Richard C. Bartlett, Susan Aspinall Block, and the National Endowment for the Humanities.

Copyright $\odot 2005$ by the University of Texas Press

All rights reserved

Printed in the United States of America

First edition, 2005

Requests for permission to reproduce material from this work should be sent to Permissions, University of Texas Press, P.O. Box 7819, Austin, TX 78713-7819.

@ The paper used in this book meets the minimum requirements of ANSI/NISO Z39.48-1992 (R1997) (Permanence of Paper).

\section{Library of Congress Cataloging-in-Publication Data}

The community forests of Mexico : managing for sustainable landscapes / edited by David Barton Bray, Leticia Merino-Pérez, and Deborah Barry. - 1st ed.

p. $\mathrm{cm}$.

Includes bibliographical references and index.

ISBN 0-292-70637-5 (cl. : alk. paper)

1. Community forests-Mexico. I. Bray, David B. II. Merino-Pérez, Leticia. III. Barry, Deborah.

SD569.C66 2005

$333.75^{\prime} 0972-\mathrm{dc} 22$ 
To the ejidatario and comunero families of the forest communities of Mexico, in the hopes that this book will be one more granito de arena toward all of us learning bow to become better forest stewards. 
THIS PAGE INTENTIONALLY LEFT BLANK 